\author{
Agnieszka ORANKIEWICZ ${ }^{1}$ \\ Artur MAJER ${ }^{2}$
}

\title{
TRENDS IN FILM INDUSTRY DEVELOPMENT IN POLAND
}

\begin{abstract}
The film industry in each country is referred to as "national cinematography". In Poland, very large changes in the cinematographic industry took place after 2005. This year, after many years of efforts, the Cinema Act regulating the financing of film production came into effect. Under the Act, it has been appointed Polish Film Institute, whose mission is to promote the development of various aspects of cinematography. The systemic framework of support for cinematography, particularly film production, is the source of tremendous interest in the Polish Film Institute and makes it the biggest player in the market. This study aims to demonstrate the development trends in Polish film production industry. Feature films co-financed by the Polish Film Institute (PISF) - the main authority in charge of public funding allocation for cinema-related endeavors in Poland - were the object of the study. The actual amounts of film budgets in Poland, the amount of co-financing and the number of films co-financed in a given year are analyzed. The article uses quantitative methods to characterize the size of the cinema market in Poland and case studies to show the problem more fully. Along with quantitative study analysis, this work employs the framework of production culture.
\end{abstract}

Keywords: creative industries, film production, film budgets, public funding.

\section{INTRODUCTION}

Cinematography is mainly a film business. But it's also the distribution of movies and display in cinemas. The film sector plays two roles simultaneously. On the one hand, it is an important element of the country's cultural life. On the other hand, it has also a great economic importance. It is one of these creative industries which with appropriate state stimulation, is capable of creating value added in the economy and new jobs ${ }^{3}$.

The audiovisual market is an important element of modern economies. The number of films produced in the world, as well as the income from their production and distribution

\footnotetext{
${ }^{1}$ Agnieszka Orankiewicz PhD, Faculty of Management, University of Łódź, Łódź 90-237, ul. Matejki 22/26, phone: (+48 42) 6356339, e-mail: agnieszka.orankiewicz@uni.lodz.pl (corresponding author).

Dr Agnieszka Orankiewicz, Wydział Zarządzania, Uniwersytet Łódzki, Łódź 90-237, ul. Matejki 22/26, tel. (+48 42) 6356339, e-mail: agnieszka.orankiewicz@uni.lodz.pl (autor korespondencyjny).

2 Artur Majer PhD, Film Art Organization, Lodz Film School, Łódź 90-323, ul. Targowa 21/23, phone: (+48) 607996693, e-mail: majarti@wp.pl.

Dr Artur Majer, Organizacja Sztuki Filmowej, Łódzka Szkoła Filmowa, Łódź 90-323, ul. Targowa 21/23, e-mail: majarti@wp.pl.

${ }^{3}$ M. Zabłocki, Organizacja produkcji filmu fabularnego w Polsce, Warszawa, 2013, p. 1.
} 
are growing steadily. In Poland audiovisual market is currently worth about 5 billion PLN, while the same film production is approximately 200 million $\mathrm{PLN}^{4}$. This study aims to demonstrate the development trends in Polish film production industry.

\section{Methodology}

Feature films co-financed by the Polish Film Institute (PISF) - the main authority in charge of public funding allocation for cinema-related endeavors in Poland - were the object of the study. The availability of PISF data allows us to determine the real values of film budgets in Poland, co-financing amounts, and the number of films co-financed in a given year ${ }^{5}$. Since the resources of the Institute are not obtained from the national budget, the sum allocated to a given production may be expended over the course of more than one calendar year. Moreover, film production is a flexible process; its duration may be extended due to unexpected events. Additionally, the fact that a film is completed does not guarantee it will be distributed, though the very purpose of feature films is to be screened in cinemas and reach a wide audience. Due to the above mentioned variables we have decided to consider the release dates of feature films, not their date of approval for PISF financing or end of production as stated in the copyright notice. Therefore, this study examines films co-financed by the Polish Film Institute premiering during the first decade of its existence - the 2006-2015 period.

Along with quantitative study analysis, this work employs the framework of production culture - an intersection of qualitative studies in the fields of ethnography, microsociology, and cultural anthropology $y^{6}$. It utilizes the knowledge accumulated through the authors' work in Polish cultural industries, as well as their experiences in the field of film and film production. All data used in the study were compiled by the authors, based on the archives of the Polish Film Institute, official information published on the www.pisf.pl website, and Polish box office charts published on the www.boxoffice.pl website.

\section{FILM PRODUCTION IN POLAND: BEFORE AND AFTER THE FOUNDING OF THE POLISH FILM INSTITUTE}

\subsection{Film production in Poland before the founding of PISF}

Polish law did not recognize "film producer" as a profession before 1989. This is particularly interesting in light of the fact that all other professions in filmmaking were extensively defined by government legislation. Film Units (organized groups of authors) fulfilled the creative and organizational duties of film producers in the present sense of the term, while the government handled the financial duties. Polish People's Republic officially owned the movies and had full authority over them. It could shelve inconvenient movies

\footnotetext{
${ }^{4}$ PricewaterhouseCoopers estimates available in the report "Why support the audiovisual production industry?" www.pisf / pwc.

${ }^{5}$ In order to improve data legibility, the amounts presented in the charts were converted to Euro, although budgets and co-financing amounts were originally calculated in Polish złoty. The amounts were converted according to the April 7, 2017 exchange rate. $€ 1=4,2194$ PLN

${ }^{6}$ M. Adamczak, Obok ekranu. Perspektywa badań produkcyjnych a spoteczne istnienie filmu. Poznań, 2014, p. 27-48.
} 
indefinitely while widely distributing others, sending them to festivals abroad and enjoying the resulting prestige and financial returns.

Following the advent of free-market economy in 1989, it turned out that the Communistera management style made Polish cinema incapable of self-financing through the exploitation of films. The government had to turn its attention to the film industry once more. It was decided that films, being objects of cultural heritage, should be co-financed by the state. Subsidies would be granted to films, not to individuals; producers would receive funds toward the production of a work, not for their personal use. The Film Production Agency (APF), formed in 1991 to oversee this process, evaluated and allocated financial resources for feature, documentary, and animated films until 2005. This financing came out of the budget of the Ministry of Culture; the number of co-financed projects and the amount of funding were decided by the Minister based on the national budget. Therefore, the amount of available resources depended on the economic programme of the governing parties and their plans for financing cultural policy. The toughest period in the history of APF - and, as a consequence, of Polish cinema - coincided with the rule of the right-wing Akcja Wyborcza Solidarność party (1997-2001) which considered film production a branch of industry that should be capable of self-financing. The diametrically opposing views of the next ruling party, the left-wing Sojusz Lewicy Demokratycznej (2001-2005) spurred the filmmaking community to begin lobbying for a new cinematography law, meant to decisively regulate the issue of public finance funding for film production. After several years of debates at the highest levels of the government, the Polish Film Institute was established in $2005^{7}$.

\subsection{PISF support for film production in Poland}

The Polish Film Institute was established on the basis of the Act on Cinematography of 30 June 2005. It is tasked with supporting the development of Polish (and European) cinema, popularizing film culture, handling film education, and promoting Polish films abroad. The Institute cannot undertake economic activities; it supports cinematographic productions by granting subsidies, or, in some cases, loans and warranties. It is the largest and most important source of state support for film production in Poland. Its funding comes from public revenue, not from taxes, unlike the APF, which was "spending part of the national budget". According to the Act, all entities which profit from films as objects of cultural heritage - i.e. distributors, cinemas, state and private television broadcasters, satellite broadcasters, and cable networks - must pay 1,5\% of their yearly revenue on behalf of PISF. The Institute then returns the entire amount to the market in the course of carrying out its legal and statutory activities. Legal entities - producers, organizations, film schools - apply for co-financing in the area of cinematography. The Institute's director decides whether to finance or reject an application after it is evaluated by a panel of experts.

The Operational Programme for Film Production allows producers to apply for co-financing both at the project development stage and at the production stage. The programme currently has several tracks for different production stages, types (feature, documentary, animation), and formulas. There are separate funding pools for minority co-productions,

\footnotetext{
${ }^{7}$ For more see: E. Zajiček, Poza ekranem. Polska kinematografia w latach 1896-2005. Warszawa, 2009 and E. Gębicka, Między państwowym mecenatem a rynkiem. Polska kinematografia po 1989 roku w kontekście transformacji ustrojowej, Katowice 2006.
} 
micro-budget films (total cost below 1500000 PLN = approx. €355 500), and production and development of films for young and family audiences. From a historical perspective, in light of over a decade of the Institute's activities, the Operational Programme for Film Production focuses on several key priorities, including Production - subdivided into classic types (feature, documentary, animation) - and Project Development. The main rule is that state co-financing cannot exceed 50\% of the film's budget; maximum amounts are limited based on the type of the project. These limits are specified in the Regulation of the Minister of Culture, the executive act of the Act on Cinematography. Producers of artistically ambitious films of low commercial value may classify them as "difficult films" and apply for co-financing of up to $70 \%$ of the budget (up to $90 \%$ until 2012); however, the limits are significantly lower in this case - only half of the amount specified for non-"difficult" films.

\section{QUANTITATIVE ANALYSIS OF FEATURE FILMS CO-FINANCED BY THE INSTITUTE}

\subsection{Production trends in feature film production in Poland (per number of premieres)}

The systemic framework of support for cinematography, particularly film production, is the source of tremendous interest in the Polish Film Institute and makes it the biggest player in the market. This can be easily observed in the number of premieres of Polish feature films co-financed by the Institute in the 2006-2015 period. 2006 was selected as the start point of the period of analysis because it was the first year when the Institute's director (Agnieszka Odorowicz) actually began issuing decisions on co-financing film production. These served as a legal basis for subsidy contracts, spending, and accounting. Therefore, films co-financed by the state via the Institute started being produced and screened that very year. Only two such films were made in 2006 itself, as film production usually takes more than a year and promotion and distribution do not always begin immediately after completion. At the same time, PISF inherited the commitments of its predecessor, the Film Production Agency, and facilitated the completion of another 14 films. Therefore, 16 of 26 feature films premiering in 2006 had been subsidized with public money, of which 2 were co-financed specifically by the Polish Film Institute. This low number began growing over time, which meant an increase in public funds allocated to co-financing film production. Figure 1 depicts this growth tendency. In the 2006-2008 period the Institute had also finalized the commitments of the Film Production Agency - 14 in 2006, 5 in 2007, and 3 in 2008. The number of all cinema premieres of Polish feature films (including minority co-productions) over the period of analysis is 365 . Public funding of film production in Poland is therefore quite high, reaching $60 \%$.

218 feature films co-financed by PISF premiered in the 2006-2015 period. The number of premieres fell significantly in 2012. This could have been caused by the economic crisis in Europe, which was perceivable in Poland, though less so than in the other countries in the region. Figure 1 shows detailed data about the number of premieres.

Over the period of analysis, the average number of premieres of feature films co-financed by the state was 22 per year. 2009 was the record year with 30 premieres, while over the last few years the number remains stable at 25 . 


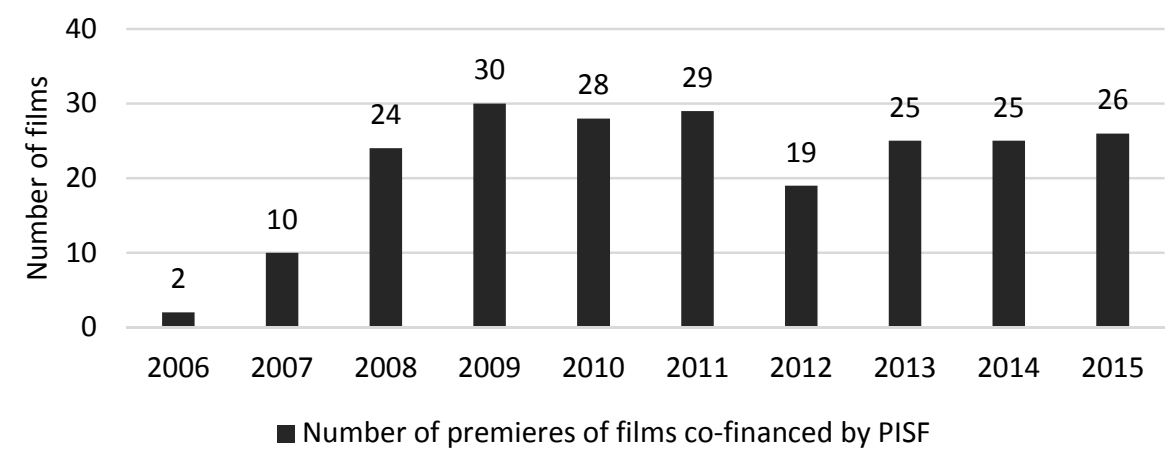

Figure 1. The number of premieres of feature films co-financed by the Polish Film Institute Source: Study authors.

\subsection{Categories of PISF co-financing for feature films}

From 2010 feature films subsidized by the Polish Film Institute fell into one of the following categories: arthouse; historical; films for young and family audiences; and potential blockbusters. The existence of these types, which can hardly be called genres, indicates the kind of productions the Institute considers relevant to its mission. The first type, arthouse films, is analogous to the "difficult films" defined in the Act: works which are artistically, formally, or technologically innovative, likely to succeed at festivals, aiming for originality over popularity. Historical movies, as the name indicates, should depict significant historical events reflected in Polish traditions and culture, and should have an educational value. Family films are projects which focus on the subject of children and teenagers in the modern world, carry significant cognitive, educational, and ethical values, and are accessible to young viewers. The Institute planned to provide loans for the last type of films, potential blockbusters: primarily entertainment-oriented, but carrying significant esthetic, cultural, and artistic values. Selecting the specific type of film they want to make, the producer and author must conform not just to the formal requirements, but also to the audiovisual culture programme supported financially by the Polish Film Institute.

\section{ANALYSIS OF FEATURE FILM BUDGETS CO-FINANCED BY PISF}

Describing film production in Poland requires an evaluation of the amount of financial resources allocated to this purpose. The analysis of feature film budgets was based on the 218 films, which premiered in 2006-2015 and was subsidized by the Polish Film Institute. In order to present the real budgets and co-financing amounts for each year, the authors have decided to present them using fixed prices, assuming of 2006 purchasing power. All analyses in the rest of the article will be performed on real values.

The top three most expensive films from that period were international co-productions in which Poland had a minority share. Carnage (premiere: 2012,) directed by Roman Polański, holds the record with 63709 723,58 PLN (approx. $€ 15099$ 2378). The amount of

\footnotetext{
${ }^{8}$ Exchange rate from 14.07.2017. $€ 1=4,2194$ PLN.
} 
PISF co-financing reached only 2,56\% of the total budget. The second largest co-production is The Courageous Heart of Irena Sendler, directed by John Kent Harrison (premiere: 2009); its budget was 35508 283,25 PLN (approx. €8 415 481) and the share of PISF cofinancing was 6,37\%. Released in 2013 and directed by Ari Folman, Congress holds the third place with 32446 154,68 PLN (approx. €7 689 755). PISF supplied 10,46\% of this production's budget. This means that budgets of minority co-productions may significantly skew the statistics of total yearly costs of Polish feature films. Therefore, the authors decided to remove any co-productions with less than $20 \%$ of PISF funding (i.e. minority co-productions) from their sample. 17 films whose budgets significantly skewed the results of the analysis were omitted. Figure 2 shows the differences between the budgets of all 2006-2015 films and the sample without minority co-productions. At the same time it is worth emphasizing that these three films represent three specific reasons why Polish Film Institute supports minority co-productions at all. Carnage was directed by one of best known polish living film artists, Roman Polanski, whose career by the way lasts for much longer then PISF's existence. The Courageous Heart... tells a story of Polish hero Irena Sendlerowa who helped saving Jews during Second World War; it was the very first feature film about her, so Polish Film Institute insisted to be a part of it. And Congress, made by foreign director with American actress Robin Wright, is the adaptation of short story written by acclaimed Polish si-fi author, Stanisław Lem. The basic reason for PISF involvement in non-Polish project are therefore Polish people taking part in it as creators, artists or characters. But on the other hand the participation of the Institute in these films makes it prestigious for the PISF itself.

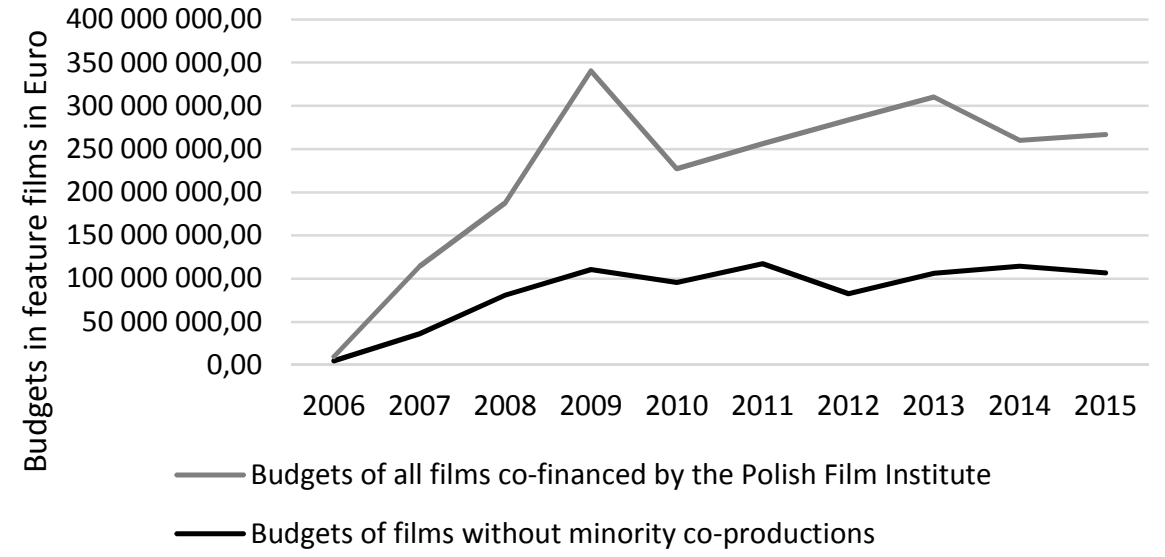

Figure 2. Budgets of feature films co-financed by PISF (in €)

Source: Study authors.

International co-production allows the filmmakers to pool funds from diverse sources and acquire a financial mechanism which allows for high production budgets. Therefore, the budgets of domestic films are significantly lower. The highest-budget film realized without foreign funding was Łukasz Barczyk's 2015 Influence, which cost 20100 687,04 PLN (approx. €4 763 873). Mariusz Gawryś's Sztuka masażu, premiering in 2009, had the lowest 
budget at 688398,88 PLN or approx. $€ 163151$. It should be noted that Sztuka masazu was approved for PISF funding in 2006. The film was finished in the same year and screened at the 31st Polish Feature Film Festival in Gdynia, winning the award for best directorial debut. However, it was only distributed to cinemas in 2009. This could be due in part to its low budget, reflected in mise-en-scène restrictions and the final shape of the project, which may have caused a lack of interest on the part of distributors and cinema owners.

Budgets - the variable being analyzed in this study - are measurable, therefore they may be synthetically expressed via measurements which express their mean levels. The most frequently used mean is the arithmetic average, based on all values of the characteristics of the objects in the set. As this data set contains outliers in the form of high-budget minority productions, the analysis merits the use of positional measurements. The median is significantly more resistant to outliers than the arithmetic average; therefore, the results obtained through its use in this study will be closer to reality.

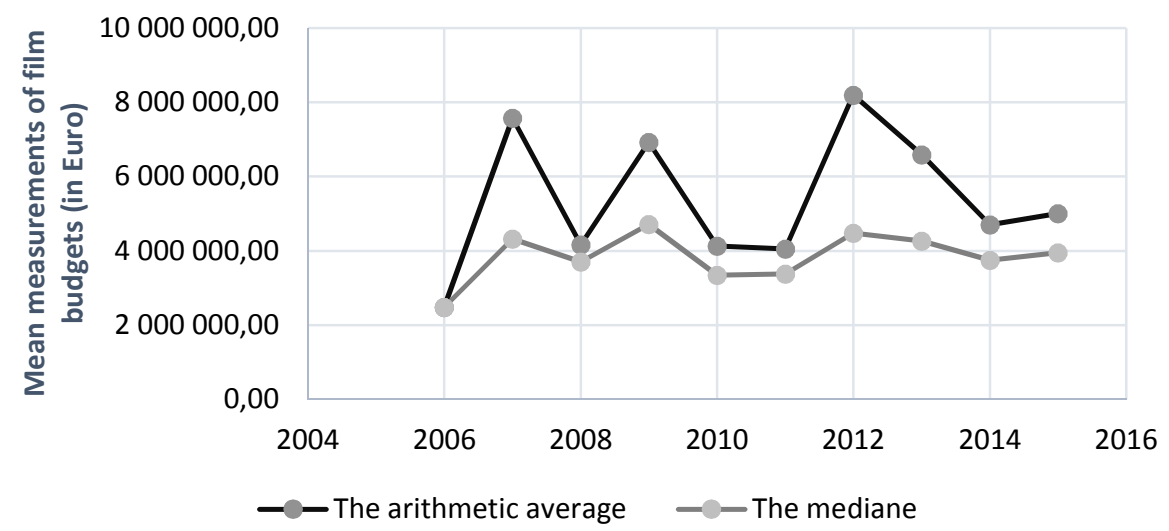

Figure 3. Mean measurements of feature film budgets (in $€$ ) subsidized by PISF (per year of premiere) Source: study authors.

Apart from the starting year, the average budget of Polish feature films falls into the 3,3-4,5 million PLN range (approx. €758 402 to $€ 1066502$ ) and remains more or less stable. Of course more expensive films exist in the data set, but they are exceptions and cannot reflect the general tendency in the size of Polish feature film budgets.

In order to present the number of films in different budget brackets, the entire set of films was broken down into 4 categories. Low-budget films under 2 million PLN (approx. $€ 474$ 000), two categories of mid-budget films at 2-4 million PLN and 4-8 million PLN, and high-budget films above 8 million PLN (approx. $€ 1896000$ ). Figure 4 shows the distribution of the data. 


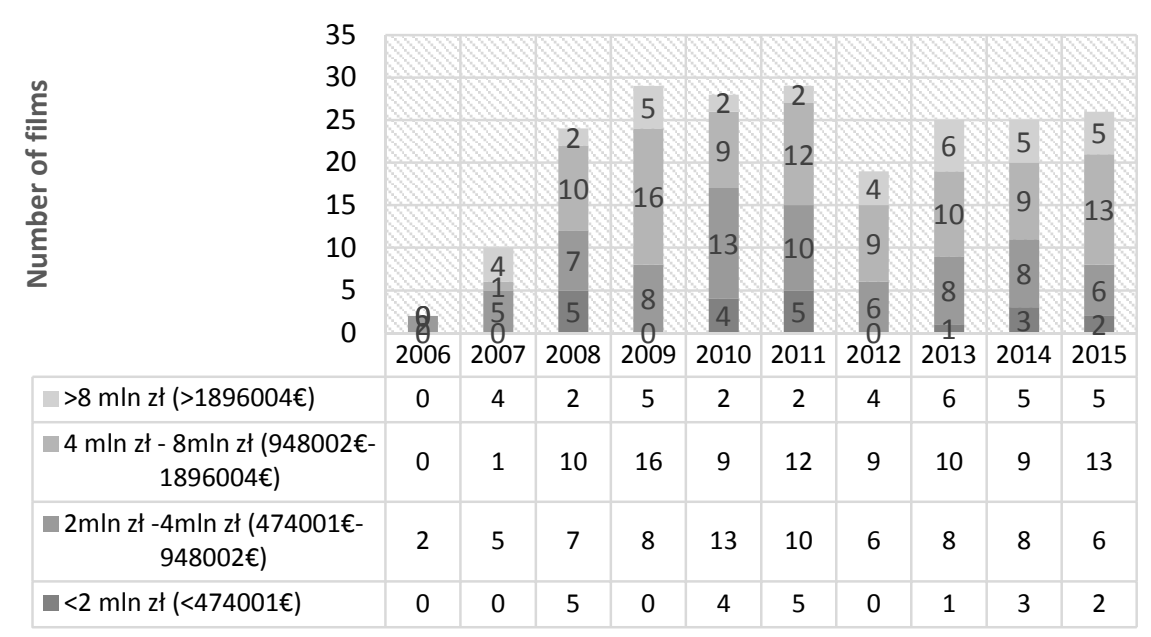

Figure 4. Distribution of the data points based on the budget category

Source: Study authors

The above analysis indicates that the majority of films produced in Poland are midbudget films in the 4-8 million PLN and 2-4 million PLN brackets. High-budget films (over 8 million PLN) are mostly international co-productions with minority financing from the Institute. Of these four categories, low-budget films received the lowest subsidies from PISF over the studied period.

\section{COMPARATIVE ANALYSIS OF FEATURE FILMS CO-FINANCED BY PISF}

\subsection{Box office and revenue}

Attendance statistics of domestic films in Poland over the studied period raise some interesting conclusions. Since the number of premieres co-financed by the Polish Film Institute grew and subsequently stabilized, it could seem that the number of viewers would climb steadily as well. However, no clear correlation could be observed. 2014 premieres attracted the largest audiences over the period of analysis. Over 8 million viewers saw Polish productions that year; this was mainly due to the 2014 premieres of Gods, Warsaw '44, and Jack Strong, which accounted for the highest number of viewers. Since the study only examines films co-financed by PISF, the data reflects only the popularity of a segment of Polish feature production. The results may seem non-representative. In the years when co-financed films attracted fewer viewers - 2006, 2008, 2011 - movies produced outside of the state support infrastructure were box-office hits. Assuming the mean production budget of a Polish feature film falls into the 3,3-4,5 million PLN bracket (approx. €0,76-1,1 million), exceeding 1 million viewers is a box-office success and generates real profit for the producer. In these years the majority of the most popular films did not have PISF co-financing: 4 in 2006, 3 in 2008, while 2 top hits of 2011 were not co-financed by PISF and one was (Battle of Warsaw 1920 directed by Jerzy Hoffman). However, it should be noted that the period of analysis includes years when only one film 
exceeded 1 million cinema viewers: 2013, 2010, and 2015. The 2015 box-office success was co-financed by PISF. Therefore, this data indicates that domestic film viewership remains an unstable market.

Revenue earned from films is another variable describing the state of the film industry in Poland. The data presented below is incomplete, as it only reflects the revenue from cinema tickets without any other sources of revenue generated by films. Admissions and screening revenue are very strongly correlated here, which may mean that ticket prices are very similar across the cinemas and screenings, causing audience numbers to directly influence revenue.

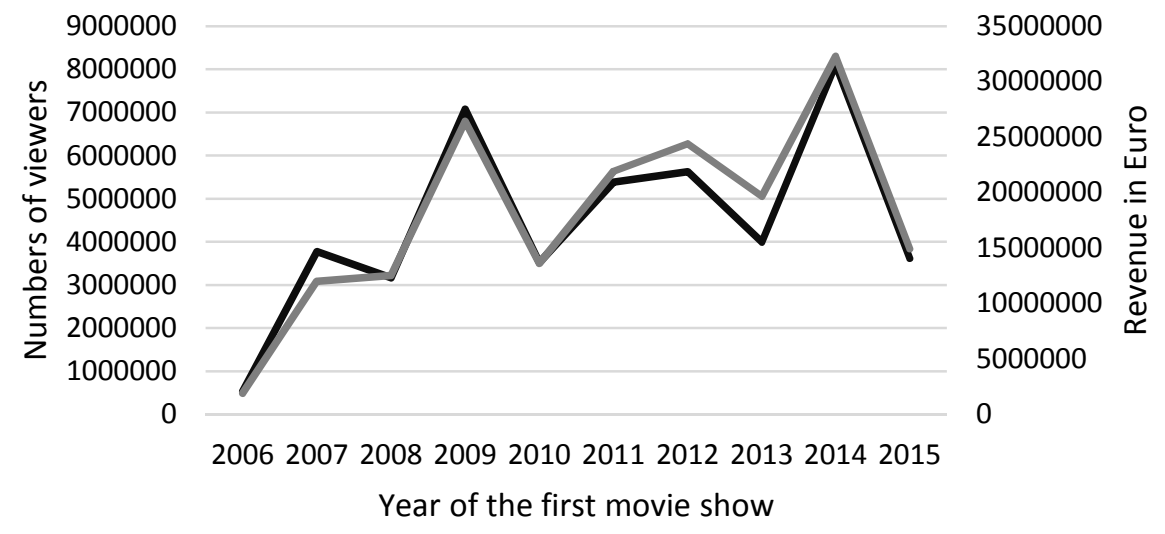

$\longrightarrow$ Number of viewers $\longrightarrow$ Revenue in Euro

Figure 5. Revenue and admissions to feature films co-financed by PISF

Source: Study authors; based on data from boxoffice.pl.

The top places in the ranking over the period of analysis are occupied by ambitious films about national history or an important individual, produced mainly for the domestic market, falling into the Institute's "arthouse" or "historical" categories. The highest revenue over the studied period (40 271552 PLN, or approx. €9 544 378) was earned by Gods, directed by Łukasz Palkowski. The movie depicts the famous Polish heart surgeon Zbigniew Religa, who performed the first heart transplant in Poland. A narrative about the Katyn massacre and the fate of Polish officers during World War II, Katyń, directed by Andrzej Wajda, had the highest viewership: 2770313 . However, the list of the most popular films of 2006-2015 is topped by a family comedy that was not co-financed by PISF, and its producers never even applied for funding: the 2015 Letters to Santa 2, directed by Maciej Dejczer, with 2968392 viewers and revenue reaching 54075180 PLN.

Revenue adjusted for subsidy amount may be an interesting indicator of the effectiveness of public finance utilization. It should be noted that this indicator is negative for most of the movies in the data set of this study, as their subsidies exceed the revenue from cinema tickets. The 2014 Gods had the highest revenue adjusted for subsidy amount. 


\subsection{Scale of financial support from the Polish Film Institute}

An evaluation of the importance of public funding in the development of Polish cinema requires us to determine the financial involvement of the Polish Film Institute in the production of feature films. It should be noted that PISF funds are not the only public funds allocated to the development of Polish cinema. Local authorities reserve a part of their budget for the development of film production in their region; Regional Film Funds, established in 2007, are tasked with the allocation of these resources. However, this only amounts to a few percent of total support for production. Public television, which receives revenues from TV licenses, invests in film production to a slightly larger extent. The Polish Film Institute remains the largest and most important public investor in the production of Polish feature films.

Table 1 compares the total budgets of feature films, yearly subsidies from the Polish Film Institute, and the percentage of PISF funding in feature film production.

Table 1. Share of PISF funding in feature film production in Poland per date of premiere

\begin{tabular}{|c|c|c|c|c|c|}
\hline Year & $\begin{array}{c}\text { Budget size } \\
\text { in } 2006 \text { prices } \\
(P L N)\end{array}$ & $\begin{array}{c}\text { Budget size in } \\
2006 \text { prices in } € \\
(€ 1=4,2194 \\
\text { PLN })\end{array}$ & $\begin{array}{l}\text { Subsidy amount } \\
\text { in } 2006 \text { prices } \\
\text { (PLN) }\end{array}$ & $\begin{array}{c}\text { Subsidy amount } \\
\text { in } 2006 \text { prices in } \\
€(€ 1=4,2194 \\
\text { PLN })\end{array}$ & $\begin{array}{c}\text { Share of } \\
\text { PISF in } \\
\text { feature } \\
\text { film } \\
\text { budgets }\end{array}$ \\
\hline 2006 & 4969111,00 & 1177681,90 & 949717,00 & 225083,42 & $19,11 \%$ \\
\hline 2007 & 75782461,03 & 17960482,78 & 19094537,56 & 4525415,36 & $25,20 \%$ \\
\hline 2008 & 99793316,39 & 23651068,02 & 32746793,69 & 7761007,18 & $32,81 \%$ \\
\hline 2009 & 207843570,21 & 49259034,51 & 55204448,40 & 13083483,05 & $26,56 \%$ \\
\hline 2010 & 115685831,21 & 27417602,32 & 46392203,96 & 10994976,53 & $40,10 \%$ \\
\hline 2011 & 117344809,11 & 27810780,94 & 58496619,29 & 13863729,27 & $49,85 \%$ \\
\hline 2012 & 163810732,83 & 38823229,09 & 37915523,12 & 8985998,75 & $23,15 \%$ \\
\hline 2013 & 164702532,80 & 39034586,15 & 56618222,29 & 13418548,20 & $34,38 \%$ \\
\hline 2014 & 117542850,67 & 27857716,90 & 47663043,21 & 11296166,09 & $40,55 \%$ \\
\hline 2015 & 130166514,58 & 30849531,82 & 48303786,29 & 11448022,54 & $37,11 \%$ \\
\hline
\end{tabular}

Source: Study authors.

PISF funding for feature films reached its peak in 2011. The Institute had co-financed almost $50 \%$ of the budgets of that year's premieres. The fact that state TV broadcaster Telewizja Polska had stopped producing films in the 2009-2010 period may have had a bearing on that - the burden of maintaining the status quo of yearly production fell squarely on PISF $^{9}$. At the same time, assuming that private funding for film production would be restricted in light of the economic crisis, the Institute approved most financing applications in the "difficult film" category (up to $90 \%$ of production budget). The highest real PISF subsidy, allocated to Być jak Kazimierz Deyna directed by Anna Wieczur-Bluszcz, covered almost $80 \%$ of its costs.

\footnotetext{
9 A. Wróblewska, Rynek filmowy w Polsce, Warszawa, 2013, p. 143.
} 
Once minority co-productions are omitted from the data set as high-budget outliers with low shares of funding from Polish public finance, financial participation of the Polish Film Institute in film production increases. In the 2006-2015 period it reached $61,51 \%$, which means that PISF funding is not merely supplementary, but key for domestic productions. In light of the fact that PISF participates in $60 \%$ of all feature film production it can be claimed that film production in Poland depends on public funds.

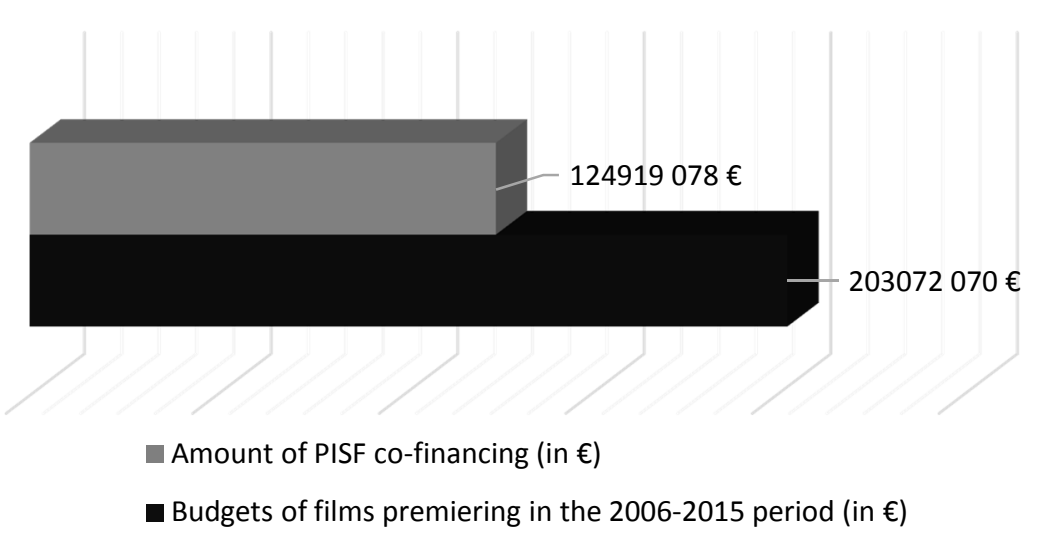

Figure 6. Amount of PISF co-financing versus budgets of films premiering in the 2006-2015 period (in €)

Source: Study authors.

\subsection{Case study: Selected films co-financed by the Polish Film Institute}

The undeniable influence of the Polish Film Institute on feature film production in Poland does not translate to their attendance numbers. Let us compare two historical films produced during the same part of the period of analysis: Warsaw ' 44 directed by Jan Komasa, released in 2014, and Influence directed by Łukasz Barczyk, released in 2015. They have several factors in common: their costs exceeded 20 million PLN in real prices from 2006 and PISF provided 6 million PLN of co-financing to each, amounting for $24 \%$ of their budgets. The directors belong to the same generation of artists; though Barczyk, 7 years older, had slightly more experience at the time of production, both men had already directed a number of feature films and television plays. Both had been successful at festivals in Poland and abroad. In addition to genre similarities, both films were produced for anniversaries - the premiere of Warsaw '44 was timed for the 70th anniversary of the Warsaw Uprising, while Influence was released for the upcoming 100th anniversary of the Greater Poland Uprising. Despite the similarities in their production, the two films performed very differently in the cinemas. Warsaw '44 attracted 1753255 viewers, bringing 26045517 PLN in ticket revenue, while Influence had 62610 viewers and 983246 PLN of revenue. Therefore it should be assumed that the former film, with revenue exceeding production costs, is a hit, while the latter, whose exploitation revenue reached $5 \%$ of production budget, is a flop. The number of awards for each film serves to confirm this assumption. While 
Influence was appreciated exclusively at festivals in Poland, only for its costume and production design, Warsaw '44 raked in awards at Polish film festivals abroad. Its director received the prestigious "Paszport Polityki" award and accolades of film critics from the Polish Filmmakers Association. These differences were mainly due to the failed promotional campaign for Influence, while advertising for Warsaw'44 was well thought out. Moreover, Influence used an avant-garde narrative structure and a campy outlook on a world where magic and reality coexist as equals. Historical facts form a backdrop to the occult activities of the protagonists. It should be noted that fantasy is not a genre traditionally present in Polish cinema, while historical films have always been popular. Warsaw' 44 shows the struggles of young people during the uprising, their fight for the country, survival, and love. It is therefore much closer to the popular blueprint for a historical melodrama with its overtones of nationality and identity. Warsaw' 44 was far better suited to the preferences of audiences interested in content centered around the widely-known history of World War II in Poland: it is worth noting that the average cinemagoer is significantly more familiar with the Warsaw Uprising than with the Greater Poland Uprising, even though the latter was a success while the former ended in a tragic fiasco for a whole generation of Varsovians and the city itself. Although formally innovative and "postmodern", Warsaw '44 remained realistic and its educational values brought entire classrooms to cinemas on school trips, while Influence proved less attractice with its raw mysticism and special effects, which in turn translated into significantly lower viewership.

The above factors clearly indicate that the involvement of the Polish Film Institute in film production and (even very high) subsidies do not guarantee success. Consumers of culture are not knowledgeable about production; they can be mainly reached by promotional materials and distribution practices. We may speculate that the aggressive promotional campaign touting Influence as a masterpiece, coupled with the negative reactions of early viewers and critics, resulted in extremely low box office numbers.

\section{CONCLUSIONS}

Production budgets of Polish feature films fall within the 3,2-4,5 million PLN range, which could be considered rather inexpensive. The Polish Film Institute co-financed, on average, more than the $60 \%$ of feature films released in the 2006-2015 period. The average share of public resources from PISF in co-financed films, barring international minority coproductions, exceeds $61 \%$. Contributions in kind cover part of the costs of these films, which makes the real contribution of the Institute to film budgets even higher. Therefore, the existence of PISF clearly stabilizes the film market in Poland, as evidenced by the constant yearly number of cinema premieres of co-financed films. The Polish film market is developing and modernizing under the influence of the provisions of the Act on cinematography and financial support distributed through the Polish Film Institute.

However, subsidy amounts do not directly correlate with the reception of co-financed films. Audience reactions depend on a number of factors outside the Institute's scope of influence, like advertising quality or final artistic decisions of the authors and producers. It is possible that the influence of PISF on the quality of Polish films would be more pronounced if the Institute served as a co-producer. Similarly, in spite a noticeable tendency in cinema viewership of co-financed films over the period of analysis, the annual box-office curve for domestic films remains unstable. Sometimes viewers choose Polish films financed 
outside the public mechanisms of support; at other times foreign productions prove more popular. Stabilizing this branch of the market and permanently attracting Polish audiences to domestic productions require long-term film education, the reach and results of which could only be successfully studied over a decade from now.

The Polish Film Institute has been performing its public purpose since 2005 by supporting difficult domestic arthouse productions which do not meet mainstream tastes. Its main task is to subsidize Polish films which could not be produced without the use of public funds. In addition, the Institute promotes international co-productions and offers loans to commercial cinema projects, which supports companies operating in the audiovisual market.

Polish film production exhibits a tendency toward an excessive dependence on public funds. Ideally, the sources of financing domestic filmmaking should be diversified. However, investing private funds in film production is risky given the uncertain returns. Attracting private capital would require financial institutions to expand their offer for film producers, as well as the creation of a cohesive system of film production insurance, as is the case in the USA.

In France for every 1 euros tax incentives were invested in the additional 12.8 euros sector, similarly in the UK every 1 pound of tax relief brought 12 pounds of added value ${ }^{10}$. Development of film production in Poland could also be bolstered by introducing corporate income tax, which provide tax breaks for producers and investors in audiovisual production. For the audiovisual production in Poland should be also consider a maximum simplification of the process of recovery by foreign producers of VAT. However, this would require numerous reforms and changes in the implementation of Polish cultural policy.

\section{ACKNOWLEDGMENT}

The authors express appreciation to the Ministry of Science for the support in financing the project No. 0135/NPRH4/H2b/83/2016, named "Filmmaking process and its organizational and economic conditions in the context of production culture research" (National Human Development Programme "Development 2b") under the direction of dr hab. Marcin Adamczak, which is held at the Polish National Film, Television and Theatre School in period from 2016 to 2019.

\section{REFERENCES}

1. Adamczak M., Obok ekranu. Perspektywa badań produkcyjnych a spoteczne istnienie filmu, Wydawnictwo Uniwersytetu Adama Mickiewicza, Poznań 2014.

2. Gębicka E., Między państwowym mecenatem a rynkiem. Polska kinematografia po 1989 roku w kontekście transformacji ustrojowej, Wydawnictwo Uniwersytetu Śląskiego, Katowice 2006.

3. Ilczuk D., Ekonomika kultury, Wydawnictwo Naukowe PWN, Warszawa 2012.

4. Wróblewska A., Rynek filmowy w Polsce, Wydawnictwo Wojciech Marzec, Warszawa 2013.

\footnotetext{
${ }^{10}$ Raport: Dlaczego warto wspierać przemyst produkcji audiowizualnej, PWC, available at
} www.pisf/pwc. 
5. Zabłocki M., Organizacja produkcji filmu fabularnego w Polsce, Wydawnictwo Wojciech Marzec, Warszawa 2013

6. Zajiček E., Poza ekranem. Polska kinematografia w latach 1896-2005, Wydawnictwo Stowarzyszenia Filmowców Polskich, Warszawa 2009.

\section{INTERNET SOURCES}

1. Raport: Wsparcie podatkowe produkcji filmowej w Polsce, PWC, available at www.pisf/pwc

2. Raport: Dlaczego warto wspierać przemyst produkcji audiowizualnej, PWC, available at www.pisf/pwc

\section{TENDENCJE ROZWOJU PRZEMYSEU FILMOWEGO W POLSCE}

Mianem „kinematografii narodowej” określa się w poszczególnych krajach przemysł filmowy. W Polsce bardzo duże zmiany w przemyśle kinematograficznym zaszły po 2005 roku. W tym roku, po wieloletnich staraniach środowiska filmowego, weszła w życie ustawa o kinematografii regulująca finansowanie produkcji filmowej. Na mocy ustawy został powołany Polski Instytut Sztuki Filmowej, którego zadaniem jest wspieranie rozwoju różnych aspektów kinematografii. Systemowe zasady wspierania kinematografii, a szczególnie produkcji filmowej sprawiają, że zainteresowanie Polskim Instytutem Sztuki Filmowej jest ogromne, a on staje się głównym graczem na rynku.

Celem artykułu jest przedstawienie tendencji rozwojowych na rynku produkcji filmowej polskiej kinematografii. Jako przedmiot badania przyjęto filmy fabularne dofinansowane przez Polski Instytut Sztuki Filmowej, który jest głównym dysponentem pieniędzy publicznych wydawanych w Polsce na przedsięwzięcia z zakresu kinematografii. Analizie poddano urealnione wysokości budżetów filmowych w Polsce, kwoty dofinansowań oraz liczbę filmów dofinansowanych w danym roku.

W artykule zastosowano metody ilościowe w celu scharakteryzowania wielkości rynku kinematograficznego w Polsce oraz studia przypadku mające na celu pełniejsze pokazanie problemu. Obok analizy badań ilościowych w tekście wykorzystano paradygmat kultury produkcji, będący pochodną badań jakościowych etnografii, mikrosocjologii i antropologii kultury.

Słowa kluczowe: przemysły kreatywne, produkcja filmowa, budżety filmowe, finansowanie ze środków publicznych.

DOI: $10.7862 /$ rz.2018.hss.83

Tekst złożono do redakcji: października 2017 r.

Tekst przyjęto do druku: grudzień 2018 r. 